\title{
EL DESPERTAR DE LA CONCIENCIA A TRAVÉS DEL ESPEJO EN ALGUNOS TEXTOS DE LITERATURA INFANTIL Y JUVENIL
}

\author{
Eva María VILLAR SECANELLA
}

Universidad de Zaragoza

\section{$\mathbf{V}$}

\section{oces que guían hacia el regreso}

Veva y el mar, Caperucita en Manhattan y Bella y Oscura son relatos pertenecientes a la literatura infantil y juvenil, protagonizados por niñas en edad iniciática, creados por mujeres escritoras y que comparten rasgos con la novela lírica de autoformación, un género que le atribuye al origen la base del conocimiento y en su voluntad de dominarlo y comprenderlo, realiza un recorrido transhistórico reflexivo como proceso formativo que, llegando a alcanzar a la misma estructura semántico-formal de la narración, implica tanto al héroe ficcional como al lector.

Biruté Ciplijauskaité en su obra La novela femenina contemporánea (1970-1985): Hacia una tipología de la narración en primera persona nos detiene en la coincidencia del alto porcentaje de mujeres escritoras contemporáneas que se inclinan por el género de la novela lírica de autoformación, recogiendo en su trabajo reflexiones de Didier $^{1}$ en las que se observa que «el yo cuenta la historia del devenir, de la auto-realización de la autora, una conciencia en movimiento constante» (Ciplijauskaité, 1988: 29) que busca su identidad propia de mujer, silenciada e ignorada durante milenios de historia, tendiendo a alejarse del discurso vinculado al significado convencional y directo, unívoco y concluso; indagando y experimentando a través de la ambigüedad, la fragmentación o los reflejos especulares en los que un intérprete activo deberá reconstruir sentidos; introduciendo una percepción del tiempo primitiva y cíclica donde en la continuidad o la repetición se encuentra una energía primigenia de características míticas capaz de abrirse hacia el descubrimiento y la transformación. Todo ello, recursos discursivos que son potenciados por una colectividad contemporánea donde se relativiza la verdad y se legitima la búsqueda individual, en ningún caso propiedad de la mujer escritora y, sin embargo, recursos de los que ella se apropia para iniciar un viaje de indagación y reencuentro con su esencia que se niega a las voces heterodiegéticas y omniscientes con autoridad y control absoluto sobre el discurso narrativo, inclinándose por la voz bajo la perspectiva del «yo» protagonista en el caso de

\footnotetext{
${ }^{1}$ La obra de Bèatrice Didier a la que se hace referencia es L'Écriture-femme, Presses Universitaires Françaises, París, 1981.
} 
El despertar de la conciencia a través del espejo en algunos textos de literatura infantil...

Veva y el Mar; el «yo» testigo en Bella y Oscura y la omnisciencia selectiva, voz narradora de Caperucita en Manhattan. Según estudios de Rodríguez Fontela, siguiendo la tipología de N. Friedman, los tres puntos de vista que destacan «en la modalización de la novela lírica de autoformación» (Rodriguez Fontela 1996: 400).

La voz narradora de Veva y el Mar -ya señalada bajo la perspectiva del «yo» protagonista- es una voz inverosímilmente reflexiva para la niña de 9 meses que representa y que, a través de esta incoherencia discursiva, parece intencionadamente romper la ilusión narrativa llamando la atención sobre el juego ficcional propuesto, tras el que se esconde, evidentemente, una voz adulta.

Ciplijauskaité considera la idea de que algunas escritoras con pudor de desnudarse públicamente en su relato, crean distancia estableciendo «un marco con la voz narrativa en primera persona para centrar luego el interés en un personaje diferente, que no habla» (Ciplijauskaité, 1988: 15).

Lo cierto es que a pesar de ser Veva la que nos relata el viaje de retorno hacia la memoria de su abuela Genoveva, hacia ese pueblo costero en el que transcurrió el pasado de la anciana, es un viaje que las dos recorren juntas y el discurso narrativo se torna ambiguo a la hora de identificar una heroína unívoca.

La afasia de Genoveva como voz narradora, como «yo» protagonista, aunque interrumpida por abundantes diálogos en los que se le permite a ella expresarse y al lector conocerla de manera directa, es un recurso estilístico que subraya la baja autoestima de Genoveva, deteriorada por unas normas sociales de raíz católico-patriarcal que ha llegado a asimilar, obstaculizándose el acceso a su conciencia de heroína y sus posibilidades de superación y transformación.

Es Ciplijauskaité también la que destaca, aludiendo a palabras de Gilligan ${ }^{2}$, el «obstáculo principal» en la evolución de la mujer: lo que ella llama su «ética del sacrificio» (Ciplijauskaité, 1988: 15) Genoveva se encuentra en un momento de su vida en el que ella misma, interiorizados los límites que su sociedad estableció para las mujeres ancianas, se siente inhibida dentro de su colectividad, desterrada a habitar, literalmente, el trastero de la casa en la que convive con su hija, su yerno y sus nietos. Ese lugar al que se destinan los objetos inútiles y del que no pasa inadvertida su connotación simbólica de invisibilidad, aunque también de aislamiento y «lo que se aísla, se redondea, adquiere la figura del ser que se concentra sobre sí mismo» (Bachelard, 1957: 299), el ser que soñando focaliza sus miedos y se prepara para el viaje.

Simone de Beauvoir es concisa con respecto al papel social de la mujer mayor: «se sabe inútil» (de Beauvoir, 1949: 393). Genoveva no se queja nunca, incluso miente bastante «para evitar problemas» (Kurtz, 1981: 12) Y así, cuando su hija y su yerno se van de vacaciones todos los veranos y ella debe ingresar en una residencia de monjas para ancianas, también miente y les hace creer «que aquello es un paraíso» (Kurtz, 1981: 12). Es un acto de abnegación por mantener el orden establecido, para complacer a su prójimo y no defraudar. Parece tratarse de un mecanismo de defensa ante la ambivalencia de un miedo entre la vergüenza y el conflicto. Por miedo a la vergüenza ocultamos y

\footnotetext{
${ }^{2}$ La obra de Carol Gilligan a la que se hace referencia es In a Different Voice. Psychological Theory and Women's Development, Hardvard University Press, Cambridge, 1982.
} 
mentimos, la vergüenza, reflexiona José Antonio Marina en su obra Anatomía del miedo, «es la conciencia de un déficit, de una falta, de una des-honra a los ojos de los demás. Es el ideal social, que a veces es infame, resonando en lo más profundo de la intimidad» (Marina, 2006: 129) Sin embargo, y sólo ante la mirada de su nieta y el lector, Genoveva se siente libre de desnudar sus verdaderos sentimientos, extendiéndose hasta el intérprete la confianza que deposita en Veva y generando lazos de complicidad a través de los que accedemos al obstáculo principal, secreto e íntimo con el que una mujer socializada en una cultura de raíz católico-patriarcal debe enfrentarse para su evolución: su carencia de auto-estima, su sentimiento de vergüenza y su miedo al conflicto. El miedo al conflicto, en el caso de Genoveva íntimamente unido al de la vergüenza,

supone, ante todo, la pérdida del amparo de las rutinas. Es un terror al cambio y, en especial, a lo imprevisto. El miedo a lo extraño, a lo nuevo, está muy extendido en el mundo animal, aunque compensado por la curiosidad, que es, precisamente, el interés por lo nuevo. Por eso se pueden dar conductas de evitación y acercamiento, en que no se sabe cuál de las dos prevalecerá, si el miedo o el interés (Marina, 2006: 117).

Genoveva sale del trastero de la casa de sus hijos para reencontrarse con su memoria, un viaje tonificante hacia el pueblo costero que habitó cuando fue joven y que la reconstruirá y a través del cual despertará a una conciencia renovada, acompañada y acompañando a su nieta, en un papel ambivalente entre heroína en tránsito de su propia construcción y maestra-ayudante en el viaje de Veva.

La novela de autoformación, nos informa Ciplijauskaité recogiendo reflexiones de Elizabeth $\mathrm{Abel}^{3}$ es la «novela del despertar» (Ciplijauskaité, 1998: 20). Relatos de inicio, de regreso al inicio, del monomito descrito por Campbell «separación-inicio-retorno» (Campbell, 1949: 35), la novela lírica de autoformación presta mayor atención a la tercera fase en una tendencia de regreso a los orígenes y la rememoración se convierte en la vía por la cual el héroe ficcional y el lector realizan un viaje de autodescubrimiento y de reconstrucción. A través de la memoria se reordena el pasado, se reorganiza el caos y se reconstruye la identidad en un acto de reflexión hacia la propia conciencia.

La conciencia rememorativa del protagonista ayuda, creemos, a evocar nuestros propios recuerdos, a definir nuestra propia experiencia, a proyectar nuestros valores, a configurar, en fin, el esquema de nuestra propia conciencia que la obra sea capaz de configurar cuando interpretamos el sentido (Rodríguez Fontela 1996: 86).

En Veva y el Mar nos encontramos ante dos modalidades diferentes de concienciación que conviven, se complementan y yuxtaponen en un mismo discurso narrativo: por un lado, y a través de la memoria, está la concienciación de Genoveva, que regresando al pueblo costero de la mujer joven que fue realiza una revisión del pasado desde el presente. Conjurar la memoria, activarla, supone un escapismo del presente a través de los reflejos que regresan del pasado; es mirarse en el espejo penetrando en su interior, buscando una imagen más allá de la inmediata. Por otro lado, se encuentra el despertar de la conciencia de la niña, de Veva, que acompañando y acompañada por su abuela, volviendo a recorrer los espacios que ella habitó y reproduciendo sus acciones como Genoveva las

\footnotetext{
${ }^{3}$ La obra de Elizabeth Abel a la que se hace referencia es The Voyage In: Fictions of Female Development, University Press of New England, Hanover y Londres, 1983.
} 
El despertar de la conciencia a través del espejo en algunos textos de literatura infantil...

realizó por primera vez en su juventud, reactualiza sucesos pasados transformando a su abuela en un ser cercano a lo primigenio, lo mítico. Mircea Eliade, reflexionando sobre los ritos de paso en sociedades pre-modernas observa:

Si se restaura el mundo al estado en que se encontraba en el momento en que nació, y si son reproducidos los gestos realizados por primera vez por los dioses al principio, la sociedad y todo el cosmos se convierten en lo que fueron: puros, poderosos, eficaces, y con todas las posibilidades intactas (Eliade, 1956: 14).

Es así como Veva adquiere el conocimiento, en un proceso de imitación o repetición ritual de su cosmogonía familiar. Ciplijauskaité recogiendo ideas de Simone de Beauvoir, reflexiona sobre las numerosas novelas contemporáneas femeninas que «presentan el paso de niña a mujer, que frecuentemente es marcado por la adquisición del recuerdo» (Ciplijauskaité, 1988: 38).

En Bella y Oscura, la obra se abre en la génesis de la heroína, cuyo discurso narrativo mantiene relaciones con el hipotexto de las Sagradas Escrituras, una génesis que remontándose al origen de la protagonista, y de manera simbólica, se hace extensible al origen de la Humanidad: «por entonces para mí aún no se había despegado el cielo de la tierra» (Montero 1993:7) A través de esta estrategia inicial, la obra manifiesta el pacto ficcional propuesto, su necesidad de retorno, su intento por recuperar la memoria de la heroína al mismo tiempo que rescata los orígenes literarios del relato. La protagonista de Bella y Oscura llega a la vida humana atravesando el caos de una memoria imprecisa, «de lo anterior tan sólo guardo un puñado de imágenes inconexas y turbias» (Montero 1993: 7), y la vida de la protagonista de Bella y Oscura se inicia por el poder que la memoria le confiere y su consecuente capacidad de recordarse, es decir, relatarse. «Por buscarle a mi relato algún principio, diré que mi vida comenzó en un viaje de tren, la vida que recuerdo y reconozco» (Montero 1993: 7) Observemos que esta limitación de la voz narradora homodiegética para discernir con claridad sus recuerdos, la convierte en una autoridad discursiva y fuente documental poco fiable, al mismo tiempo que se subraya de manera explícita, la confusión en la dicotomía historia/ficción de cualquier texto biográfico.

Ambas novelas, Bella y Oscura y Veva y el Mar se abren desde el caos, «cada repetición ritual de la cosmogonía viene precedida por una regresión simbólica al caos» (Eliade, 1956: 14) Sin embargo, el caos sugerido por Veva y el Mar se desdramatiza a través de un lenguaje coloquial en tono lúdico que guía al lector facilitándole el camino hacia el significado y focalizando ese «caos», a pesar de que se dilate el momento de darle nombre al conflicto: «Todo eran silencios, todo se resolvía en mirarme con caras compungidas, besarme a cada momento, decirme cosas cariñosas que me gustaban mucho, pero no dejaban de escamarme porque no venían a cuento» (Kurtz 1981: 5), en un acontecimiento concreto y, por tanto, controlable: su hermana Natacha se casa y los padres se irán de vacaciones dejando solas a Veva y a su abuela. «El peor de los terrores siempre es aquel imposible de nombrar, sin forma concreta, sin contornos...» (Álvarez, 2011: 111).

Por otra parte, Veva, y muy al contrario que la protagonista de Bella y Oscura, asegura no haber perdido jamás la memoria, es decir, la conciencia de sí misma. Se recuerda, sin mostrar confusión, incluso antes de nacer, rechazándose el caos pre-humano y, por tanto, la experiencia perturbadora de 
desorden. «Tengo muy buena memoria. Fíjate: me acuerdo en donde estaba antes de nacer. ¿Me crees?» (Kurtz, 1981: 123).

Las novelas de autoformación -como se viene analizando- dan un valor esencial a la memoria, la cual adquiere connotaciones sagradas y nos remite a un hipotexto de carácter iniciático. En las culturas primitivas, la memoria de la tribu también poseía cualidades sagradas y su transmisión y conocimiento le ofrecía al iniciado las facultades de transformación en ser adulto y le capacitaba para ingresar como miembro de la colectividad. María de los Ángeles Rodríguez Fontela, aludiendo a las palabras de E. Welty ${ }^{4}$ nos induce a la reflexión sobre las semejanzas que se encuentran en el acto de descubrir y recordar. «A medida que descubrimos recordamos; al recordar, descubrimos, y esto lo experimentamos con mayor intensidad cuando convergen nuestros viajes interiores» (Rodríguez Fontela, 1996: 85).

Ante el relato de Bella y Oscura y Caperucita en Manhattan, observamos grandes diferencias con respecto al de Veva y el mar. Cabe destacar que Bella y Oscura, así como Caperucita en Manhattan, son novelas escritas en la década de los noventa y aunque han sido abordadas por un público adolescente, gracias, entre otros factores, a programas educativos como el promovido por la DGA Invitación a la Lectura ${ }^{5}$ su destinatario original es de carácter universal, por el contrario, Veva y el Mar es un relato escrito para un público infantil de la década de los ochenta y quizá sea este el motivo, o al menos uno de los motivos, por el que del mismo modo que Veva es acompañada por su abuela en su viaje iniciático, sin apenas momentos de soledad y frecuentemente limitada a imitar, escaseando los desvíos, el camino previamente recorrido por su abuela; así el discurso narrativo escolta al lector a través de un lenguaje cotidiano con el que podrá identificarse fácilmente y alcanzar un significado directo. En Bella y Oscura, sin embargo, la ambigüedad del significado se acentúa, la iniciación a la sensualidad de la palabra se intensifica regresando a su condición mítica y cumpliendo uno de los rasgos habituales dentro de la novela lírica de autoformación. Del intérprete se requiere una participación activa, reanimar la palabra en un amplio desplazamiento hacia el sentido, hacia el origen del lenguaje, ese instrumento, nos dice Janer Manila, «a través del cual se hacen explícitas su identidad y su presencia histórica» (Janer Manila, 2002: 82) Y es esa ambigüedad de la palabra, sin el apoyo de la identificación inmediata, la que manifiesta las intenciones de un texto que busca provocar la desorientación en el lector y estimularlo hacia la imaginación y la rememoración de su propia experiencia vital en la reconstrucción de sentidos.

Veva y el Mar, alejándose de ciertos aspectos de la novela lírica de autoformación, parece proteger al intérprete de la sensación de abandono y del sentimiento de angustia ante la pérdida de sentido, tan necesaria en el héroe, por otra parte, para sobreponerse a sí mismo, descubrir significados

\footnotetext{
${ }^{4}$ La obra de Eudora Welty a la que se hace referencia es La palabra heredada. Mis inicios como escritora, Montesinos, Barcelona, 1988.

5 Programa nacido en Aragón en el año 1985 con el objetivo de dinamizar la lectura entre los jóvenes. Docentes y estudiantes de ESO o de bachiller trabajaban sobre una obra literaria y posteriormente recibían en sus centros al autor, con el que se mantenía un diálogo directo sobre la obra objeto de estudio. El programa se cerró en el año 2010 sometido a los recortes de la política educativa actual.
} 
El despertar de la conciencia a través del espejo en algunos textos de literatura infantil...

propios y superar su realidad inmediata. Este relato, a pesar de su marcado interés por la memoria y la perspectiva de una voz narradora desde el «yo» protagonista, se inclina por una descripción rememorativa basada en la repetición presente de acciones pasadas en las que intervienen frecuentemente elementos de carácter simbólico que invitan a la evocación, pero evita aproximarse a los procesos psicológicos de sus heroínas, debilitando la activación de la propia conciencia rememorativa del lector. Se trataría más bien de una autobiografía narrativizada que interiorizada, manteniendo la acción un papel relevante.

La voz narradora de Bella y Oscura adopta una perspectiva tendente al «yo» testigo, una voz con una autoridad subjetiva, parcial y confusa sobre la historia y que se encuentra en una posición ambigua con respecto a lo narrado, dado que a pesar de ser un personaje homodiegético, no siempre cumple una función protagónica en la acción de la historia y con frecuencia su función principal es la de espectador, aproximándose de este modo al narrador heterodiegético. Sin embargo, como señala Rodríguez Fontela (1996), el Bildungsroman ya no es una historia de acción sino «una historia de conciencia» en la que el héroe a partir de la rememoración experimenta una «reflexión autocognoscitiva» en la que se redescubre. Una autoformación que privilegia la iniciación individual pero que se lleva a cabo, como el propio discurso narrativo manifiesta, dentro de una colectividad determinada.

Es de forma especular, a través de los personajes-héroes que interactúan y conviven dentro de un mismo espacio ficcional como a la voz narradora «testigo» de Bella y Oscura y al lector se les van revelando los secretos que envuelven la historia de la familia de la protagonista. El descubrimiento es el punto de unión que identifica tanto a la voz narradora como al lector debilitando las jerarquías y compensando la autoridad sobre el texto.

La voz narradora heterodiegética de Caperucita en Manhattan es la voz heterodiegética y omnisciente del hipotexto del cuento maravilloso con autoridad total sobre el discurso, aunque paulatinamente, a medida que avanza la narración, irá cediéndole autoridad a la voz de Sara, transformándose en una voz omnisciente selectiva que en un viaje de descenso hacia el interior de la psique de la adolescente, llegará hasta la fusión con la voz de la protagonista a partir de un estilo indirecto libre o, más concretamente tomando terminología de Dorrit Cohn recogida por Rodríguez Fontela, un monólogo narrativizado por su grado de extensión y subjetividad. Una perspectiva, por otra parte, propia de la novela lírica de autoformación por su capacidad para descubrir los conflictos internos del personaje y estados anímicos cercanos a un sueño o delirio individual que ayudan al lector a conocer y reconocerse en el héroe ficcional, al mismo tiempo que encuentra claves en el proceso formativo personal. Este viaje de dirección descendente, de sensación de caída, que guía la voz narradora a través del discurso narrativo, se repite en la presentación de otros dos personajes a los que esta estrategia también les confiere una relativa autoridad sobre el relato: El Dulce Lobo y Miss Lunatic, tornándose de este modo, la voz omnisciente selectiva, en voz omnisciente selectiva variable. La voz narradora relaja definitivamente su autoridad, fragmentándose, aceptando la convivencia de varias perspectivas. Un recurso que revela la relatividad de la verdad al mismo tiempo que incide en 
su carácter de ocultamiento, invitándole al intérprete, una vez más desde la experiencia del descubrimiento, a desplazarse hacia la reconstrucción de sentidos.

Gadamer, recogiendo apreciaciones de Martin Heidegger, reflexiona sobre la relación etimológica que mantienen las palabras verdad y desocultación. «Aletheia significa propiamente desocultación y nos induce a la reflexión sobre el hecho de que la verdad tenga que ser arrebatada del estado de ocultación y encubrimiento» (Gadamer, 1975: 53). Esta idea coincide plenamente con las teorías de Mircea Eliade cuando nos informa sobre la iniciación de la pubertad, en el mundo primitivo, como un rito de paso que, por encima de todo representa «la revelación de lo sagrado, entendiéndose por sagrado no sólo lo que hoy entendemos por religión, sino todo aquello que conforma la cultura de la tribu» (Eliade, 1956: 22).

El viaje transhistórico por nuestra construcción cultural humana se evidencia en Caperucita en Manhattan en la convivencia, dentro de un mismo espacio textual, de diferentes hipotextos, un recurso que una vez más, en su tendencia de regreso al inicio, remite a un tiempo cíclico primitivo, continuo y cambiante.

A los personajes de Caperucita en Manhattan, aunque héroes contemporáneos y normalizados, se les yuxtaponen una serie de características que parecen indagar en su génesis, una génesis que rescata sus orígenes literarios y manifiesta su naturaleza ficcional. La génesis de Miss Lunatic, como madre del escultor de la estatua de la Libertad, se encontraría dentro de un hipotexto histórico, aunque simultáneamente, sus características extraordinarias y longevidad inhumana la conectan a un hipotexto mítico o épico como Diosa de la Libertad. Este tiempo primigenio y sagrado que la construye, continuo y cambiante sincrónicamente, se evidencia a través de las anamorfosis que experimenta, sólo visibles para la mirada de Sara - la niña protagonista de Caperucita en Manhattan- como si a través de un espejo mágico fuera capaz de percibir la transfiguración. «Sara (...) notó que la presión de aquella mano se acentuaba. Le dio un brinco el corazón. La mano de miss Lunatic no tenía arrugas como antes, era más blanca y alargada y el tacto de su mano se notaba suave» (Martín Gaite, 1990: 136). La misma Sara Allen, una niña cercana a la realidad cotidiana de cualquier lector, se irá transformando en la heroína de un hipotexto extraído de Robinson Crusoe, Alicia en el País de las Maravillas o muy especialmente Caperucita Roja. En esta tendencia de eterno retorno y búsqueda de la génesis literaria de los personajes: historia y fábula, realidad y ficción se contaminan; así como la confusa memoria de la voz narradora homodiegética de Bella y Oscura ubicaba su autobiografía, de manera explícita, en un espacio ambivalente entre historia y ficción. La intertextualidad de Caperucita en Manhattan, no se conforma con referencias de exclusividad literaria, extendiéndose a diferentes lenguajes de expresión a lo largo de la cultura humana, hacia el cómic, la música o el cine, invitando el texto a un «juego de memoria» donde la voz narradora potencia «el recuerdo de otros textos que presentarán similares características, dificultades o alternativas en su expresión y/o recepción» (Mendoza, 2001: 3). Del mismo modo que Bella y Oscura utiliza un estilo discursivo, ya señalado, de conexión intertextual con las Sagradas Escrituras o textos míticos. 
El despertar de la conciencia a través del espejo en algunos textos de literatura infantil...

Para que se produzca la comunión con el texto, la experiencia lectora, «el deleite sensorial e intelectual» (Tabernero, 2009: 28) deberemos ser capaces de escapar de los arquetipos, de los clichés, del convencionalismo del signo, deberemos movernos hasta lo más profundo de nosotros mismos, hasta la memoria olvidada en «un penoso trabajo de lectura y de interpretación de las apariencias que debe marchar como al revés y en sentido contrario del trabajo de lo que llamamos falsamente la vida, como deshaciendo lo que está hecho» (Larrosa, 1996: 134).

\section{El concepto de origen y la reconciliación con el padre}

Es interesante comprobar cómo en estas tres novelas escritas y protagonizadas por mujeres encontramos la constante de «reconciliación con el padre»: «es bien sabido que las mujeres sienten mucho apego por sus recuerdos infantiles (...) Sienten nostalgia por ese periodo. Es porque en aquella época sentían sobre su cabeza la mano benévola e imponente del padre...» (de Beauvoir, 1949: 437). Una protección $\mathrm{y}$, ante todo, un reconocimiento que parece ir perdiendo, dentro de sistemas patriarcales, a medida que va construyéndose como mujer adulta. La carencia de reconocimiento paterno, en todo caso, le obstaculiza a la heroína alcanzar la plenitud y concluir la unidad del monomito descrita por Campbell y quizá sea esta la razón por las que muchas mujeres escritoras, indagando en su conciencia de mujer, sientan esta necesidad de reconciliación y reconocimiento en su colectividad patriarcal.

La baja autoestima de Genoveva la obliga a vivir aislada en un trastero, la paraliza para sobreponerse a sus miedos y ampliar su realidad inmediata. Sin embargo, una fuerza impulsora que regresa desde su memoria en forma epistolar y en la figura de tito Juan, llega hasta ella brindándole la posibilidad de reconciliarse con su pasado y reinterpretarse. Tito Juan, el hermano menor del primer marido de Genoveva, se enfadó con ella y se fue a América cuando esta, tras quedar viuda, se casó por segunda vez. No habían vuelto a tener contacto, pero ahora tito Juan ha regresado al pueblo costero en el que vivieron todos juntos con la primera familia de Genoveva y las invita a ella y a su nieta a que vayan a visitarlo. «Me ha escrito pidiéndome perdón por su silencio, por su rencor. Quiere reconciliarse conmigo y nos ha invitado a Veva y a mí a pasar el verano en la casa que fue de sus padres» (Kurtz, 1981:26).

Tito Juan representa una figura masculina protectora, tanto para Genoveva como para Veva y la necesidad de «reconciliación con el padre» es la que le lleva a Genoveva a viajar hacia su memoria, regresar al origen, acceder al mar y reencontrase consigo misma. El mar es una imagen que se encuentra fuertemente vinculada a lo femenino y al origen de la vida. La novela lírica, como fuente poderosa de revelación, remueve los orígenes simbólicos de la palabra, nos traslada a ese «antes de la conciencia», activa nuestra memoria más profunda, reflecta imágenes en cadena flotante, facilitándonos la posibilidad de reconocer nuestro yo más profundo. El mar se niega a la linealidad del tiempo, representa simultáneamente la duración ininterrumpida y lo transitorio. Posee cualidades misteriosas y purificadoras. Zambulléndose en el mar, Genoveva alcanza la transformación simbolizada en un rejuvenecimiento físico. En su transformación, redescubre sus pasos jóvenes y 
firmes capaces de recorrer caminos complejos. «No hay mejor masaje para los pies que andar por pedruscos. Y si además los bañas con agua de mar y los secas al sol... el reúma, a hacer gárgaras » (Kurtz, 1981: 127).

Narciso admira su imagen perfecta y conclusa, «la mujer se mira buscando; el agua que la refleja es movida» (Ciplijauskaité, 1988: 206) Y curiosamente es agua también lo que doña Bárbara, la abuela de la protagonista de Bella y Oscura, pide ante su inminente viaje hacia la muerte, quizá como una forma de buscar y capturar el reflejo de una identidad y una conciencia que siente extinguirse. «En ocasiones murmuraba: -Agua. Y lo decía con mucha finura y sentimiento, como quien nombra a una persona amada» (Montero, 1993: 135) Bárbara es una instancia narrativa con una relativa autoridad sobre el texto, el discurso narrativo apenas nos permite escucharla de manera directa, sin embargo cuando lo hace, y muy especialmente a medida que se acerca hacia su muerte, su voz irrumpe a través de palabras o frases de significado ambiguo que tienden al monólogo interior, una técnica utilizada con frecuencia por la novela lírica y que se encuentra vinculada a lo espontáneo y, en cierta medida, a un recurso usado por el psicoanálisis en el que se recomienda verbalizar sin seleccionar.

En Veva y el Mar -como ya se ha indicado- los accesos a desvíos en la búsqueda de una trascendencia individual se encuentran obstaculizados, entre otros factores, por los escasos espacios de soledad que las heroínas habitan o el débil seguimiento en sus procesos psicológicos a favor de la acción. Sin embargo, esos elementos simbólicos que intervienen en la acción, le invitan al lector a la evocación y a un recorrido individual que, Ciplijauskaité, recogiendo reflexiones de Jung, señala que «emerge claramente sólo cuando se asimila el material subconsciente» (Ciplijauskaité, 1988: 27).

La aportación de Genoveva, en su viaje de regreso a la colectividad, se encuentra simbolizada en la herencia que el tito Juan quiere compartir con ella. Es común en el cuento maravilloso que las protagonistas pertenezcan a una clase social baja, hecho explícitamente destacado en heroínas de la LIJ y también en Genoveva. No es extraño que la trascendencia alcanzada por estas heroínas se proyecte simbólicamente en un ascenso económico-social, pero la estrechez que logran superar, habitualmente, contiene un componente de orden espiritual reflejado, aunque ciertamente de manera implícita en el caso que nos ocupa, cuando tito Juan le dice a la abuela Genoveva: «espero que no sigas durmiendo en el trastero» (Kurtz, 1981: 119) Sin embargo, y de alguna forma, la herencia dada y no conquistada de Genoveva subraya su carácter pasivo, acentuado cuando se decide que entre tito Juan y su yerno gestionarán su dinero. La protección masculina que Genoveva, de manera voluntaria, requiere al final del relato, nos muestra un alto grado de dependencia no resuelto.

Lo que Ciplijauskaité denomina la técnica del «espejo de las generaciones» (Ciplijauskaité, 1988: 38) para mostrar cambio y continuidad en la existencia femenina es evidente en estas tres novelas. En el caso de Veva y el Mar, el lazo que mantiene unida a la niña con su abuela es especialmente estrecho, Veva como continuidad, prolongación o réplica, parte intrínseca y perteneciente a su abuela, la heredera de su universo, de sus miedos y de su mayor obstáculo como heroína: la carencia de autoestima reflejada nítidamente en el momento en que tito Juan las guía hacia el mar por caminos deshabitados y abruptos y Veva confiesa «Tito no parecía darse cuenta de que 
Buela era muy vieja y yo muy pequeña» (Kurtz, 1981: 63-64); y como si de una única onda acústica se tratara regresando a su emisor, el eco de la voz de Genoveva, abriéndose en diálogo, reverbera un miedo replicado «Hubiera sido mejor quedarnos en la playa, Juan. Estos no son caminos para mis años ni para Veva» (Kurtz, 1981: 63-64). Sin embargo, esta sensación circular donde la continuidad prevalece sobre el cambio, no se encuentra hermética y definitivamente cerrada, el discurso narrativo propone ciertas brechas. Genoveva, regresando al paraíso perdido de su juventud y llevando consigo a la niña, a su nieta como representación simbólica de un estado pre-consciente de posibilidades abiertas, se permite a través de ella el regreso a un origen anterior a la adquisición de la cultura en la que fue socializada y ambas, en simbiosis, a través de la corriente de energía que recíprocamente se transfieren, en el paralelismo antagónico, en la asimilación de opuestos, el movimiento de asfixia circular se transforma en tiempo cíclico con apertura al cambio. La maduración de Veva se refleja de manera explícita al final del viaje, de regreso al hogar, en el capítulo que cierra la obra con su primer cumpleaños «Empiezo a ser mayor» (Kurtz, 1981: 140), mientras que en Genoveva su transformación se encuentra simbolizada a través de su sanación y rejuvenecimiento físico. «Buela, quizá porque no le duelen los pies, anda más airosa, menos encogida que antes» (Kurtz, 1981: 142).

Tito Juan representa la reconciliación con el padre y la fusión con el origen. La seducción que le impulsa al héroe al viaje hacia la «plenitud esférica» conlleva siempre, y de alguna forma, un componente de agitación sensual. La atracción platónica que las heroínas de Veva y el Mar experimentan por tito Juan se erotiza tímidamente a través de las primeras hipótesis pronunciadas por la voz de la pequeña Veva acerca del motivo que los separó en el pasado: «A lo mejor quería casarse contigo» (Kurtz, 1981: 16). Una voz - no lo olvidamos- tras la que se esconde una adulta. Una insinuación erótica en la que el discurso narrativo insiste a través de la figura masculina del mismo tito Juan el que, comparándose con el lobo de Caperucita, adopta simbólicamente características de tentación: «Y ¿para qué quieres tener los ojos tan grandes, tito? Para verte mejor, Veva, como dijo el lobo a Caperucita» (Kurtz, 1981: 142). Tentación hacia el descubrimiento en un viaje de concienciación donde la sexualidad también se considera espacio de exploración. «En muchos casos, los ritos de pubertad, en uno u otro sentido, implican la revelación de la sexualidad, pero para todo el mundo premoderno, la sexualidad también participa de lo sagrado» (Eliade, 1956: 22). Sin embargo, y a pesar de que «Buela disfruta llamando a tito, casi cada día» (Kurtz, 1981: 142), se niega a sí misma la posibilidad erótica, nuevamente, inhibida por razones de raíz católico-patriarcal: «Juan tiene diez años menos que yo» (Kurtz, 1981: 16).

La figura de la abuela, hipotexto en el cuento maravilloso, simboliza la tradición. Es la figura relacionada con el ayudante del héroe que, según los estudios antropológicos de Mircea Eliade o Joseph Campbell se encuentra vinculada al hipotexto de los ritos primitivos de iniciación en los que el maestro que acompaña al neófito en su viaje es un adulto que ha superado con éxito las pruebas de iniciación a su cultura y a través de las cuales se le reveló el conocimiento de su sociedad. Su papel es protagónico, ayuda al héroe a construir sentidos y avanzar en una iniciación de autodescubrimiento, al mismo tiempo que le confiere la cultura de su colectividad y él mismo supone un modelo social. Estos 
maestros femeninos que acompañan a la heroína representan una tendencia de regreso al origen de la Madre Universal y, teniendo en cuenta que son portadores y transmisores del conocimiento, también reflejan ciertas tendencias matriarcales dentro de su colectividad. Sin embargo, Genoveva, a pesar de ser una maestra para Veva, se encuentra limitada, como ya se ha analizado, por miedos adquiridos y transmitidos por su cultura.

Gadamer realiza una reflexión acerca de la relación que mantienen autoridad y tradición:

Hay una forma de autoridad que el romanticismo defendió con un énfasis particular: la tradición. Lo consagrado por la tradición y por el pasado posee una autoridad que se ha hecho anónima, y nuestro ser histórico y finito está determinado por el hecho de que la autoridad de lo transmitido, y no sólo lo que se acepta razonablemente, tiene poder sobre nuestra acción y sobre nuestro comportamiento. Toda educación reposa sobre esta base... (Gadamer 1975: 348).

Todo aquello que desde niños nos es transmitido, tanto si ya de adultos pretendemos combatirlo como conservarlo, tiene poder sobre nuestra acción y nuestro comportamiento.

Veva es una heroína con un dominio extraordinario sobre el lenguaje que se verá inducida, por las recomendaciones de su abuela, a ocultar su verdadera naturaleza para mantener el orden y no preocupar a los mayores: «tienes nueve meses y a esa edad los niños dicen lo justo. Sigue comportándote como hasta ahora y todo irá bien. Haz como si no comprendieras» (Kurtz, 1981: 15). Pero Veva infringe la prohibición, y le confiesa a tito Juan, como si de un ayudante con mayor autoridad que Genoveva se tratara, secretos sobre su competencia lingüística nunca hasta entonces confesados a nadie, ni siquiera a su abuela. Y a través de una experiencia que difiere de la de su abuela, Veva es lanzada a la duda por tito Juan: «¿Qué mal hay en que hables y todo lo demás?» (Kurtz, 1981: 133) Advirtamos que, en estas tres obras, aquellos ayudantes que logran proyectar a las heroínas hacia las dudas más arriesgadas e incitarlas a los tránsitos más alejados de su colectividad son, todos ellos, ayudantes ajenos a su círculo familiar a los que se les concede, en cierta medida, una mayor autoridad que a sus propias abuelas por la proximidad que manifiestan con respecto al concepto de origen que el discurso narrativo encierra y hacia el que, tanto a la heroína ficcional como al lector, se estimula a desvelar. En Veva y el Mar, tito Juan, como maestro masculino, posee una experiencia personal de vinculación más estrecha con el concepto de origen dentro de una sociedad católico-patriarcal. Aunque no olvidamos que a pesar de ser tito Juan el demiurgo que guía a Veva y Genove va hacia la cala, es en último término el mar -símbolo femenino relacionado con el inicio de la vida- y su inmersión en él, el que generará la transformación en nuestras heroínas.

Veva, desnudando su verdadera naturaleza ante el lector y tito Juan, se aleja de los caminos señalados por la experiencia de su abuela y encuentra el reconocimiento. Sin embargo, ella es la heredera de la cultura de Genoveva, de su forma de ver y organizar la realidad, incluso de su nombre. El discurso narrativo parece no concederle a Veva un desvío más allá de la duda cuando le contesta a tito Juan sobre el motivo de su silencio: «-Los papás tienen miedo de que yo crezca demasiado aprisa y los deje. Ellos son felices creyendo que soy una niña como las otras» (Kurtz, 1981: 134). Un discurso narrativo protector y paternalista propio del contexto histórico-social en el que vivieron tanto Genoveva como Carmen Kurtz, su creadora. Un discurso que muestra los obstáculos contra los que 
El despertar de la conciencia a través del espejo en algunos textos de literatura infantil...

tuvieron que luchar las heroínas de una determinada época, pero al mismo tiempo, su insuficiente grado combativo, las condena a reproducirse en la afasia.

Airelai es una de las maestras de la protagonista de Bella y oscura, ajena a su círculo familiar y con mayor autoridad que su propia abuela. Será una de las voces que más asiduamente irrumpa en el relato de Bella y Oscura a través de la inserción de relatos metadiegéticos que la convierten en una relevante instancia narrativa. Airelai es una heroína híbrida y ambigua, una ayudante envuelta en misterio por su personalidad de características antagónicas y no siempre positivas desde una ética convencional, así como sus supuestas facultades extraordinarias que la ligan a un caos primigenio y pre-humano vinculado, por otro lado, al origen mítico de la palabra; una palabra que ella domina y a través de la cual se relata. «las palabras crean mundos, y son capaces de crearme ahora» (Montero, 1993: 21). Una heroína en tránsito entre la novela épica y la picaresca, una diosa que presionada por su contexto social ejerce la prostitución. «La enana había sido diosa, pero ya no lo era. Porque se puede ser dios y luego dejar de serlo (...) No hay nada seguro en este mundo» (Montero, 1993: 81). Airelai, relatándose, del mismo modo que la narración mítica, pretende penetrar en el caos primigenio de su existencia, extensible al de la Humanidad, conocerlo y dominarlo, construirse una conciencia donde el concepto de verdad convencional se desvanece: ella es el producto de su propio relato. Miss Lunatic, la maestra con mayor autoridad sobre Sara, comparte ciertas similitudes con Airelai, relacionadas -y ya observadas- con su hibridación y tránsito entre lo divino y lo humano. Miss Lunatic es un ser ligado a lo primigenio desde un concepto del origen que, a pesar de partir de un caos pre-humano, como en el caso de Airelai, se distancia de su energía destructora atribuyéndole a Miss Lunatic características exclusivamente positivas desde una ética socialmente establecida y transfiriéndole el discurso narrativo a este personaje la tarea de un comentario didáctico apenas ambiguo y de significado prudentemente directo en el que se invita al lector a una reconstrucción de sentidos desde los valores que esta obra aprecia como correctos.

Para mí vivir es no tener prisa, contemplar las cosas, prestar oído a las cuitas ajenas, sentir curiosidad y compasión, no decir mentiras, compartir con los vivos un vaso de vino o un trozo de pan, acordarse con orgullo de la lección de los muertos, no permitir que nos humillen o nos engañen, no contestar que sí ni que no sin haber contado antes hasta cien como hacía el Pato Donald... Vivir es saber estar solo para aprender a estar en compañía, y vivir es explicarse y llorar... y vivir es reírse (Martín Gaite, 1990: 94).

En Bella y Oscura, la necesidad de reconciliación con el padre es explícita y nuestra heroína espera durante toda la novela, como en el hipotexto de Pippi Calzaslargas, el reencuentro con su padre, una estrategia más que marca el deseo de regreso hacia el origen. El encuentro con su padre, contrariamente al caso de Pippi Calzaslargas, se produce, aunque de forma fugaz y, sin embargo, suficiente para descubrirle su identidad. «Baba» es una palabra que ha acompañado a la heroína desde la infancia y a la que recurre, como por invocación, cada vez que se siente en peligro. «Baba» es una palabra talismán, una palabra que encuentra su fuerza en la sonoridad del lenguaje, en su fase primigenia y oral y que nos remite al hipotexto de los conjuros o las oraciones donde la palabra adquiere connotaciones mágicas y capacidad transformadora, así como a los primeros balbuceos humanos. «Tú tienes que ser Baba»-le dice su padre cuando se reencuentran. Y así es como la niña 
protagonista, la pequeña Bárbara y con ella el lector, recuperan la memoria olvidada y les es revelado que en el origen de la palabra «Baba», extensible a los primeros balbuceos humanos, se halla su propia identidad, reactivándose el carácter mítico de la palabra en una tendencia de regreso tan característica de la novela lírica de autoformación.

El sentido de la espera se desdobla y erotiza proyectado en las narraciones contadas por Airelai, ella también aguarda la llegada de un ser querido con el que compartía todo «menos la cama»a pesar de que Airelai lo deseara vehemente. Describiendo esta pasión: «siempre fui torpe, menos con él. Siempre fui débil, menos con él. Siempre fui enana menos con él» (Montero, 1993: 154), la voz de Airelai nos remite, en un juego de reflejos alcanzado por el paralelismo sintáctico, a la voz de doña Bárbara confesándole a su nieta las emociones sentidas ante su marido, el ser que amó: «siempre fui mala, menos con él. Siempre fui demasiado grande y torpe, menos con él. Siempre fui egoísta, menos con él» (Montero, 1993: 79). El discurso narrativo mantiene al lector en la intriga, dilatando el momento de descubrirle que Baba y Airelai comparten en su espera el deseo de reencuentro con el mismo hombre en el que implícita y explícitamente se proyecta la necesidad de regreso al origen como promesa de plenitud y salvación para la heroína y la colectividad que habita, el símbolo de unidad del monomito: «va a venir mi padre y nos salvará a todos» (Montero, 1993: 158).

En Caperucita en Manhattan neófita y maestra, Sara y su abuela Rebeca, también sienten una atracción de características similares por el mismo hombre hasta el grado, cuando Aurelio abandona a Rebeca, de reflejarse a través de los procesos psicológicos sufridos por la nieta, emociones identificables con la experiencia de una ruptura: el dolor de la escisión y la urgencia de reencuentro. «Estuvo varios días con fiebre muy alta y en sus delirios llamaba a Aurelio Roncali, decía que quería entrar en el Reino de los Libros, que él era su amigo, que tenía que volver» (Carmen Gaite, 2005: 42) Sin embargo, Sara, aunque lo deseó, nunca llegó a ver a Aurelio, y él jamás regresó, manteniéndose intangible el encuentro. Supo de su existencia por medio de las conversaciones mantenidas entre los adultos de su familia y los regalos que le hacía llegar a través de su madre, extendiéndose sobre Aurelio un halo de misterio, una figura mítica por su vinculación a un origen inaprensible. El primer regalo que Sara recibe de Aurelio, cuando sólo tenía dos años, y por tanto antes de haber adquirido el significado convencional de las grafías, es un rompecabezas que la acerca a las letras y todas sus posibles combinaciones, un juego a partir del cual Sara inventa palabras sinsentido o de sentido abierto. A estas palabras inventadas, hipotexto de un tipo de literatura oral primigenea relacionada con los trabalenguas o el cancionero infantil en general, Sara las define como «farfanías» y le producen placer su sonido y el sentido secreto que sólo ella entiende.

Es el intento de Sara por alejarse de su conocida cotidianidad en busca de caminos inexplorados y es el juego que se le propone al lector. Un signo que se oculta jugando al escondite con su intérprete, entreteniéndolo en el camino, conduciéndolo al misterio, al silencio, a «un tránsito que habrá de ser hacia el sentido» (Blesa 2010: 14). 
El despertar de la conciencia a través del espejo en algunos textos de literatura infantil...

En el sentido-sonido de la palabra de nuestros primeros pactos orales se descubre el camino de regreso a la condición mítica de la palabra. Desplazándose hacia el origen del lenguaje, reactivando su poder iniciático.

Aurelio, un demiurgo paternal de características similares a las de tito Juan, aunque intangible y con un grado de erotización más acentuado que este último, se acerca a Sara a través de regalos tan extraordinarios para ella que se convertirán en objetos mágicos; un amor utópico y pasional, el primero «en inyectarle sus dos pasiones fundamentales: la de viajar y la de leer [...] o sea soñar que se viajaba» (Martín Gaite, 2005: 44). El primero en llamarla a la aventura del viaje guiándola hacia su origen, abriéndola hacia su capacidad más humana: la simbólica.

El retroceso a los orígenes uniendo a tres generaciones en el eterno retorno es un recurso especialmente apreciable en Caperucita en Manhattan, manifestándose la continuidad y el cambio en la construcción de conciencia de mujer en un juego de espejos a través del dualismo y las sombras que reflejan la asociación de opuestos.

La abuela de Sara, en una técnica de desdoblamiento, es al mismo tiempo Gloria Star: la mujer joven que fue, enérgica y rebelde, la cantante de music-hall, la diva, la maestra-ayudante de connotaciones sino míticas al menos ficcionales; y Rebeca: la mujer anciana que vive en el caos y la soledad, la heroína inconclusa todavía en tránsito que no ha logrado alcanzar, a pesar de su edad, el reconocimiento dentro de su colectividad.

La simbiosis, el ritual primigenio de devoración a partir del cual el neófito ingiere y participa de la energía de la maestra, es mucho más explícito en Bella y Oscura que en Caperucita en Manhattan o Veva y el Mar. Baba, en soledad y secreto, se introduce en la pequeña cama baúl donde duerme la enana Airelai, admitiendo que «no encajaba del todo» (Montero, 1993: 129) dentro de la estrechez de ese espacio, pero de todos modos, sintiéndose protegida en ese interior descrito como un lugar «cálido y rosado» de cualidad «carnal y dulce» (Montero, 1993: 129) en el que a través de la connotación de ese espacio simbólico, tan próximo a las «fantasías intrauterinas» (Freud, 1919: 2502) de Freud, se percibe el estado embrionario de Baba transformándose en Airelai: «yo era una enana, pequeña, muy pequeña; y sabía que nada malo podría sucederme mientras me mantuviese dentro de esa penumbra circular, de ese aire tibio y nutritivo» (Montero, 1993: 129). Baba, durante su proceso de metamorfosis, conjurará al origen a través de su palabra talismán «baba-baba-baba» (Montero, 1993: 129) Del mismo modo que Sara, el día en que por primera vez se queda sola en casa de su abuela, conjura su palabra talismán «miranfú» antes de entrar en el cuarto de su abuela y descubrir sus cartas, sus fotos, sus recuerdos, sus secretos esparcidos caóticamente por encima de la cama y sentirse «Gloria Star en persona» (Martín Gaite, 1990: 66) Sin embargo, el grado de incomodidad adoptando este papel, se acentúa en el caso de Sara cuando admite que el aspecto catastrófico que presentaba el dormitorio de su abuela «dificultaba seguir jugando a ser Gloria Star» (Martín Gaite, 1990: 65).

Finalmente, y gracias a la intervención de Sara, Gloria Star encuentra el amor en el Dulce Lobo, un empresario rico, el Rey de las Tartas. Final feliz, hipotexto del cuento maravilloso tradicional en el que la abuela de Sara, como Cenicienta, parece definitivamente, alcanzar la plenitud y su lugar dentro 
de la colectividad y donde, a través de una fluctuación de roles, Sara se transforma en la ayudante de su abuela.

Sin embargo, los finales felices de Bettelheim se muestran escépticos en el marco de una sociedad descreída. «Final feliz, ¿para quién?- se pregunta Rodríguez Fontela- ¿para el lector?, ¿para el autor?, ¿para la protagonista? ¿Qué pautas rigen tales valoraciones?» (Rodríguez Fontela, 1996: 73). Los Bildungsromane son novelas de final abierto, dejando una vez más evidenciar la inefabilidad de la verdad y un viaje de autodescubrimiento hacia el origen, hacia una identidad siempre en constante formación.

A Sara le complace ese final para la historia de Gloria Star y la del Dulce Lobo, pero le resulta insuficiente para ella misma, un final ajeno, no propio. Alcanzada la reconciliación con el padre a través de su abuela, trasciende el símbolo de plenitud, perfecto y concluso proyectado en un hombre, dispuesta a conquistar su camino de regreso al origen. Desmarcándose de los pasos de su abuela y de los finales pre-establecidos y perpetuados por las mujeres de su colectividad, Sara, partiendo de la casa de Rebeca, desde su tradición, saldrá a la búsqueda de un final propio desplazándose hasta el subterráneo - una imagen en la que se aprecia la energía uterina y embrionaria- que la llevará al interior de la estatua de la Libertad.

La madre de Sara representa una refracción opuesta al caos de Rebeca. La realidad de Vivian se delimita férreamente a partir de la precaución, la rutina y el orden. El discurso narrativo mueve al intérprete hacia la hipótesis de la posibilidad transformadora y carácter iniciático que conlleva el viaje que ambas, madre e hija, realizan todos los sábados a casa de la abuela Rebeca por medio de los rituales de repetición y comprobación, próximos a conjuros protectores ante el miedo por lo imprevisto y la pérdida de control, que Vivian realiza antes de la partida.

[...] la señora Allen, después de comprobar que dejaba cerrada la llave del gas, que la nota para su marido quedaba encima de la nevera en lugar bien visible y que ninguno de los grifos goteaba, se ponía a repasar cosas dentro de su bolso, mientras las iba nombrando entre dientes. [...] Cerraba con tres llaves que metía en tres cerraduras colocadas a alturas diferentes, y luego llamaba al ascensor. Desde aquel momento cogía a la niña fuertemente de la mano y no la soltaba hasta que llegaban a casa de la abuela (Martín Gaite, 1990: 52).

Este carácter obsesivo de Vivian y su temor al cambio, no llega a suponer de manera concluyente una figura negativa, más bien parece que el discurso narrativo se esforzara por reconocer, como Ciplijauskaité nos detiene en reflexiones propuestas por Ulanov, los aspectos sombríos del yo, los miedos de nuestro inconsciente, y tratara de dominarlos dándoles forma y figura en la imagen de Vivian. Y de hecho, si Sara Allen puede soñar y finalmente decidir recorrer sola el viaje de regreso a casa de su abuela es, en alguna medida, por la seguridad que otorga el conocimiento adquirido en el ritual de repetición en el que todos los sábados la inició su madre, recorriendo juntas el camino desde su casa a casa de la abuela. El ritual del que parte aunque definitivamente se desvíe del camino convencional y transitado por su colectividad en busca de un descubrimiento individual y propio simbolizado en la Estatua de la Libertad. 
El despertar de la conciencia a través del espejo en algunos textos de literatura infantil...

\section{Referencias bibliográficas}

ÁlvareZ, Blanca (2011): La verdadera historia de los cuentos populares. Madrid, Ediciones Morata. BaChElard, Gaston (1957): La poética del espacio. DF México, Fondo de Cultura Económica, 1965. BEAUVOIR, Simone de (1949): El segundo sexo. Volumen I. Los hechos y los mitos. Madrid, Ediciones Cátedra, 2000.

BlesA, Túa (2010): Gimferrerías. Zaragoza, Editorial Eclipsados.

CAMPBell, Joseph (1949): El héroe de las mil caras. Psicoanálisis del mito. México D.F, Fondo de Cultura Económica, 1984.

CIPLIJAUSKAITÉ, Biruté (1988): La novela femenina contemporánea (1970-1985): Hacia una tipología de la narración en primera persona. Barcelona, Editorial Anthropos.

EliAdE, Mircea (1956): Nacimiento y renacimiento. El significado de la iniciación en la cultura humana. Barcelona, Editorial Kairós, 2007.

FreUd, Sigmund (1919): Obras Completas, VII. Madrid, Editorial Biblioteca Nueva, 1974.

GADAMER, Hans-George (1975): Verdad y método I. Salamanca, Ediciones Sígueme, 1995.

JANER MANILA, Gabriel (2002): Infancias soñadas y otros ensayos. Madrid, Fundación Germán Sánchez Rupérez.

KuRTZ, Carmen (1981): Veva y el Mar. Barcelona, Editorial Noguer, 1983.

LARROSA, Jorge (1996): La experiencia de la lectura. Estudios sobre literatura y formación. Barcelona, Editorial Laertes.

MARINA, José Antonio (2006): Anatomía del Miedo. Un tratado sobre la valentía. Barcelona, Editorial Anagrama, 2007.

Martín Gaite, Carmen (1990): Caperucita en Manhattan. Madrid, Ediciones Siruela, S.A, 2005.

Mendoza Fillola, Antonio (2010): «La experiencia lectora desde la Literatura Infantil y Juvenil: Reconociendo intertextos», en http://www2.ubu.es/ginves/hum_edu/dillubu/Ponencias/ Antonio_Mendoza_Fillola.pdf (última consulta, 15-10-2012).

Montero, Rosa (1993): Bella y Oscura. Barcelona, Editorial Seix Barral, 1999.

RODRÍGUEZ FONTELA, María de los Ángeles (1996): La novela de autoformación: una aproximación teórica e histórica al «Bildungsroman» desde la narrativa española. Kassel: Universidad de Oviedo: Reichenberger.

TABERnero SAla, Rosa (2009): «Leer mirando. El libro-álbum en la promoción de hábitos lectores. Claves para una poética de su lectura», en Literatura Infantil y matices. I Encuentro Internacional de Estudio y Debate. Tarazona, Fundación Tarazona Monumental, pp. 9-44. 